\title{
Intraneuronal pyroglutamate-Abeta 3-42 triggers neurodegeneration and lethal neurological deficits in a transgenic mouse model
}

\author{
Oliver Wirths $\cdot$ Henning Breyhan · Holger Cynis · \\ Stephan Schilling · Hans-Ulrich Demuth • \\ Thomas A. Bayer
}

Received: 22 April 2009/Revised: 3 June 2009/Accepted: 6 June 2009/Published online: 23 June 2009

(C) The Author(s) 2009. This article is published with open access at Springerlink.com

\begin{abstract}
It is well established that only a fraction of $\mathrm{A} \beta$ peptides in the brain of Alzheimer's disease (AD) patients start with $\mathrm{N}$-terminal aspartate $\left(\mathrm{A} \beta_{1 \mathrm{D}}\right)$ which is generated by proteolytic processing of amyloid precursor protein (APP) by BACE. N-terminally truncated and pyroglutamate modified $A \beta$ starting at position 3 and ending with amino acid $42\left[\mathrm{~A} \beta_{3(\mathrm{pE})-42}\right]$ have been previously shown to represent a major species in the brain of AD patients. When compared with $\mathrm{A} \beta_{1-42}$, this peptide has stronger aggregation propensity and increased toxicity in vitro. Although it is unknown which peptidases remove the first two N-terminal amino acids, the cyclization of $\mathrm{A} \beta$ at N-terminal glutamate can be catalyzed in vitro. Here, we show that $\mathrm{A} \beta_{3(\mathrm{pE})-42}$ induces neurodegeneration and concomitant neurological deficits in a novel mouse model (TBA2 transgenic mice). Although TBA2 transgenic mice exhibit a strong neuronal expression of $A \beta_{3-42}$ predominantly in
\end{abstract}

O. Wirths, H. Breyhan and H. Cynis contributed equally to this work.

Electronic supplementary material The online version of this article (doi:10.1007/s00401-009-0557-5) contains supplementary material, which is available to authorized users.

O. Wirths · H. Breyhan · T. A. Bayer $(\bowtie)$

Division of Molecular Psychiatry, Department of Psychiatry,

University of Goettingen, Von-Siebold-Strasse 5,

37075 Goettingen, Germany

e-mail: tbayer@gwdg.de

O. Wirths $\cdot$ H. Breyhan $\cdot$ H. Cynis $\cdot$ S. Schilling

H.-U. Demuth - T. A. Bayer

International Alzheimer PhD Graduate School,

Gottingen, Germany

H. Cynis · S. Schilling $\cdot$ H.-U. Demuth

Probiodrug AG, Biozentrum, Halle (Saale), Germany hippocampus and cerebellum, few plaques were found in the cortex, cerebellum, brain stem and thalamus. The levels of converted $A \beta_{3(\mathrm{pE})-42}$ in TBA2 mice were comparable to the APP/PS1KI mouse model with robust neuron loss and associated behavioral deficits. Eight weeks after birth TBA2 mice developed massive neurological impairments together with abundant loss of Purkinje cells. Although the TBA2 model lacks important AD-typical neuropathological features like tangles and hippocampal degeneration, it clearly demonstrates that intraneuronal $A \beta_{3(\mathrm{pE})-42}$ is neurotoxic in vivo.

Keywords Amyloid - Transgenic model - Neuron death · Neurodegeneration - Behavior · N-truncated Abeta

\section{Introduction}

Long-standing evidence shows that progressive cerebral deposition of $A \beta$ plays a seminal role in the pathogenesis of Alzheimer's disease (AD). There has been great interest, therefore, in understanding the proteolytic processing of APP and the enzymes responsible for cleaving at the $\mathrm{N}$ - and C-termini of the $\mathrm{A} \beta$ region. Besides $\mathrm{A} \beta$ peptides starting with an aspartate at position 1, a variety of different $\mathrm{N}$-truncated $\mathrm{A} \beta$ peptides has been identified in $\mathrm{AD}$ brains. Ragged peptides with a major species beginning with phenylalanine at position 4 of $\mathrm{A} \beta$ have been reported as early as 1985 by Masters et al. [36]. This finding has been disputed, as no $\mathrm{N}$-terminal sequence could be obtained from cores purified in a sodium dodecyl sulfatecontaining buffer, suggesting that the N-terminus is blocked [16, 59]. In 1992, Mori et al. first described the presence of $A \beta_{3(\mathrm{pE})}$ using mass spectrometry of purified $\mathrm{A} \beta$ protein from $\mathrm{AD}$ brains, explaining the difficulties in 
sequencing the amino-terminus [41]. They reported that only $10-15 \%$ of the total $A \beta$ isolated by this method begins at position 3 with $A \beta_{3(\mathrm{pE})}$. Saido et al. [52] showed for the first time that $A \beta_{3(\mathrm{pE})}$ represents an important fraction of $\mathrm{A} \beta$ peptides in $\mathrm{AD}$ brain, which was later verified by other reports using $\mathrm{AD}$ and Down's syndrome post-mortem brain tissue $[18,19,23,25,28,29,38,45,46,49,53,63]$. $\mathrm{N}$-terminal deletions in general enhance aggregation of $\beta$-amyloid peptides in vitro [47]. $\mathrm{A} \beta_{3(\mathrm{pE})}$ has a higher aggregation propensity [20, 55], and stability [30], and shows an increased toxicity compared with full-length $\mathrm{A} \beta[51]$.

Mouse models mimicking AD-typical pathology, such as deficits in synaptic transmission [24], changes in behavior, differential glutamate responses, and deficits in long-term potentiation are typically based on the overexpression of full-length amyloid precursor protein (APP) [39]. Learning deficits [2, 21, 43, 48] were evident in different APP models, however, $A \beta$-amyloid deposition did not correlate with the behavioral phenotype [22]. In the past, $A \beta$ has been regarded as acting extracellularly, whereas recent evidence points to toxic effects of $A \beta$ in intracellular compartments $[64,68]$. In addition, another concept favors that toxic forms of $A \beta$ are soluble oligomers and $\beta$-sheet containing amyloid fibrils $[26,58]$. It has been demonstrated that soluble oligomeric $\mathrm{A} \beta 42$, but not plaque-associated $\mathrm{A} \beta$ correlates best with cognitive dysfunction in $\mathrm{AD}$ [37, 42]. Oligomeres are formed, preferentially, intracellularly within neuronal processes and synapses rather than extracellularly $[60,66]$. Previously, we have reported that intraneuronal $A \beta$ rather than extracellular plaque pathology correlates with neuron loss in the hippocampus [8], the frontal cortex [11], and the cholinergic system [10] of APP/PS1KI mice expressing transgenic human mutant APP751 including the Swedish and London mutations on a murine knock-in (KI) Presenilin 1 (PS1) background with two FAD-linked mutations $\left(\mathrm{PS}_{\mathrm{M} 233 \mathrm{~T}}\right.$ and $\left.\mathrm{PS} 1_{\mathrm{L} 235 \mathrm{P}}\right)$. The APP/PS1KI mice exhibit robust and learning deficits at the age of 6 months [67], agedependent axonopathy [71], neuron loss in hippocampus CA1 together with synaptic deficits, and hippocampus atrophy coinciding with intraneuronal aggregation of $\mathrm{N}$-terminal-modified $\mathrm{A} \beta$ variants [4].

The APP/PS1KI mouse model exhibits a large heterogeneity of $\mathrm{N}$-truncated $\mathrm{A} \beta_{x-42}$ variants [8]. It is impossible to decipher the true toxic peptides from those, which might only co-precipitate. Therefore, we generated a new mouse model expressing only $\mathrm{N}$-truncated $\mathrm{A} \beta_{3(\mathrm{pE})}$ in neurons, and demonstrate for the first time that this peptide is neurotoxic in vivo inducing neuron loss and an associated neurological phenotype.

\section{Materials and methods}

Transgenic mice

The generation of murine thyrotropin-releasing hormone$\mathrm{A} \beta$ fusion protein mTRH-A $\beta_{3 \mathrm{Q}-42}$ was essentially as described elsewhere [12]. The respective cDNA was inserted into the vector pUC18 containing the murine Thy1 sequence applying standard molecular biology techniques and verified by sequencing. The transgenic mice were generated by male pronuclear injection of fertilized C57B1/6J oocytes (PNI, generated by genOway, Lyon, France). The resulting offspring were further characterized for transgene integration by PCR analysis and after crossing to $\mathrm{C} 57 \mathrm{Bl} / 6 \mathrm{~J}$ wildtype mice for transgene expression by RT-PCR. The line with the highest transgene mRNA expression was selected for further breeding (named TBA2).

The generation of APP/PS1KI mice (a generous gift by Dr. Laurent Pradier, Sanofi-Aventis, Paris) has been described previously [8]. All mice named as PS1KI were homozygous for the mutant PS1 knock-in transgene (KI). The APP/PS1KI mice harbored one hemizygous APP751SL transgene in addition to homozygous PS1KI. The mice were backcrossed for more than ten generations on a C57BL/6J genetic background. APP/PS1KI were crossed with PS1KI mice generating again APP/PS1KI and PS1KI mice, therefore, all offspring carried homozygous PS1KI alleles. All animals were handled according to the German guidelines for animal care.

\section{Immunohistochemistry and histology}

Mice were anaesthetized and transcardially perfused with ice-cold phosphate-buffered saline (PBS) followed by $4 \%$ paraformaldehyde. Brain samples were carefully dissected and post-fixed in $4 \%$ phosphate-buffered formalin at $4{ }^{\circ} \mathrm{C}$. Immunohistochemistry was performed on $4 \mu \mathrm{m}$ paraffin sections. The following antibodies were used: 4G8 (Aß17-24, Signet), GFAP (Chemicon), Iba1 (Waco), ubiquitin (DAKO), AT8 (Innogennetics), PS199 (Biosource), activated caspase-3 (Chemicon), calbindin (Swant), and 2 antibodies against $A \beta$ with pyroglutamate at position 3 (a generous gift of Dr. Takaomi Saido [52]; American Research Products). Biotinylated secondary antirabbit and anti-mouse antibodies (1:200) were purchased from DAKO. Staining was visualized using the ABC method, with a Vectastain kit (Vector Laboratories) and diaminobenzidine as chromogen. Counterstaining was carried out with hematoxylin. For fluorescent staining, AlexaFluor488- and AlexaFluor594-conjugated antibodies (Molecular Probes), was used. 
Quantification of $A \beta_{x-42}$ and $A \beta_{3(\mathrm{pE})}$ by ELISA

Brains were weight in frozen state and directly homogenized in a Dounce-homogenizer in $2.5 \mathrm{ml} 2 \%$ SDS, containing complete protease inhibitor (Roche). Homogenates were sonified for $30 \mathrm{~s}$ and subsequently centrifuged at $80,000 \mathrm{~g}$ for $1 \mathrm{~min}$ at $4^{\circ} \mathrm{C}$. Supernatants were directly frozen at $-80^{\circ} \mathrm{C}$. The resulting pellets were resuspended in $0.5 \mathrm{ml} \mathrm{70 \%} \mathrm{formic} \mathrm{acid} \mathrm{(FA)} \mathrm{and} \mathrm{sonified} \mathrm{for} 30 \mathrm{~s}$. Formic acid was neutralized with $9.5 \mathrm{ml} 1 \mathrm{M}$ Tris and aliquots were directly frozen at $-80^{\circ} \mathrm{C}$. SDS lysates were used in a 10-fold dilution for both $\mathrm{A} \beta_{x-42}$ and $\mathrm{A} \beta_{\mathrm{N} 3(\mathrm{pE})}$ ELISAs. Formic acid lysates were used in a 10-fold dilution for the $\mathrm{A} \beta_{x-42}$ measurement. For $\mathrm{A} \beta_{3(\mathrm{pE})}$ measurements undiluted FA lysates were used. ELISA measurements were performed according to the protocol of the manufacturer (IBL Co., Ltd. Japan; cat. no. JP27716 and JP27711). For statistical analyses, $A \beta_{x-42}$ and $A \beta_{3(\mathrm{pE})}$ concentrations resulting from SDS and formic acid extractions were cumulated.

\section{Statistical analysis}

Differences between the groups were tested with one-way analysis of variance (ANOVA) followed by unpaired $t$ tests. All data are given as mean \pm SEM. Significance levels of unpaired $t$ tests are given as follows: $* * * P<0.001 ; * * P<0.01 ; * P<0.05$. Survival rate was calculated by the Log-rank test. All calculations were performed using GraphPad Prism version 4.03 for Windows (GraphPad Software, San Diego, CA, USA).

\section{Results}

Generation of transgenic TBA2 mouse line

In addition to $\mathrm{A} \beta$ starting with aspartate at position 1 $\left(\mathrm{A} \beta_{1 \mathrm{D}}\right)$, one major $\mathrm{A} \beta$ species in $\mathrm{AD}$ brain starts at position 3 with pyroglutamate $\left(A \beta_{3(\mathrm{pE})}\right)$ that can be converted from N-terminal glutamate $\left(A \beta_{3 E}\right)$ or glutamine $\left(A \beta_{3 Q}\right)$ (Fig. 1a). We generated a novel mouse model that expresses $A \beta_{3-42}$ peptides under the control of the Thy-1 promoter. The TBA2 line expresses A $\beta$ with $\mathrm{N}$-terminal glutamine $\left(\mathrm{A} \beta_{3 \mathrm{Q}-42}\right)$ as a fusion protein with the pre-pro-sequence of murine thyrotropin-releasing hormone (mTRH) (Fig. 1b), for transport via the secretory pathway [12].

Phenotypic characterization of TBA2 mice

The TBA2 transgenic mice revealed obvious macroscopic abnormalities, including growth retardation, cerebellar atrophy, premature death (Fig. 2), and a striking neurological a

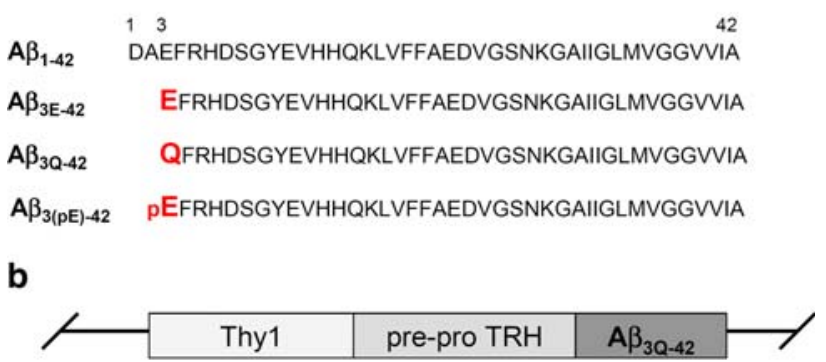

C

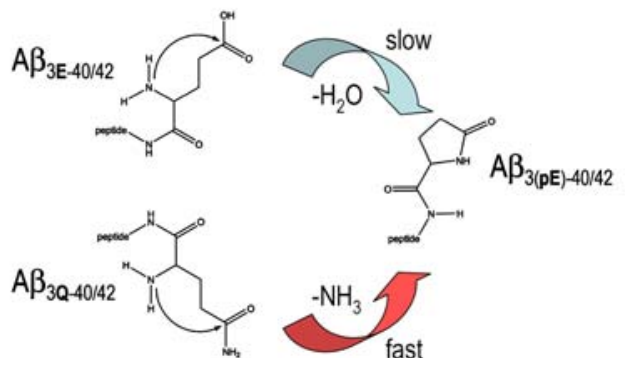

Fig. 1 Sequence of $A \beta_{1-42}$ and $N$-terminal truncated $A \beta$ starting at position 3. a $\mathrm{A} \beta_{1-42}$ starts at position 1 with aspartate $(D), \mathrm{A} \beta_{3 \mathrm{E}-42}$ at position 3 with glutamate $(E)$, and $\mathrm{A} \beta_{3 \mathrm{Q}-42}$ with glutamine $(Q)$. Both $\mathrm{N}$-truncated $A \beta_{3 \mathrm{E}-42}$ and $A \beta_{3 \mathrm{Q}-42}$ peptides can be converted into pyroglutamate- $A \beta_{3(\mathrm{pE})-42}$. b Schematic drawing of the transgenic vector. TBA2 transgenic mice express $A \beta_{3(Q)-42}$ under the control of the Thyl promoter fused to the signal peptide of the pre-prothyrotropin-releasing hormone. $\mathbf{c} N$-terminal $A \beta$ starting with glutamate $\left(A \beta_{3 E}\right)$ or glutamine $\left(A \beta_{3 Q}\right)$ at position 3 serves as substrates for generation of $A \beta_{3(\mathrm{pE})}$. The conversion of pyroglutamate from $\mathrm{N}$ terminal glutamate $(E)$ is slow, in contrast to fast pyroglutamate $(\mathrm{pE})$ formation from glutamine $(Q)$ [12]

phenotype characterized by loss of motor coordination and ataxia (Supplementary videos 1-3). The body weight at 2 months of age was significantly reduced in TBA2 mice (females $12.20 \pm 0.95 \mathrm{~g}$, males $17.60 \pm 0.51 \mathrm{~g}$ ), compared with wildtype (WT) control littermates (females $19.90 \pm$ $0.40 \mathrm{~g}$, males $24.43 \pm 1.23 \mathrm{~g}$, both $P<0.001)$. Only one of three TBA2 founder mice was fertile, and was studied in more detailed manner (named TBA2 line).

Quantification of $\mathrm{A} \beta_{x-42}$ and $\mathrm{A} \beta_{3(\mathrm{pE})}$ levels

Protein quantification of $\mathrm{A} \beta_{x-42}$ and $\mathrm{A} \beta_{3(\mathrm{pE})}$ levels in brain lysates WT, APP/PS1KI, and TBA2 mice revealed significant differences (Fig. 3). Although WT mice generated very low amounts of murine $\mathrm{A} \beta_{x-42}$ (WT, $1.29 \pm 0.9$ pg/mg w.w.), 2-month-old APP/PS1KI mice showed high $\mathrm{A} \beta_{x-42}$ levels $(35,191 \pm 773.1 \mathrm{pg} / \mathrm{mg}$ w.w. $)$, which were increased in 6-month-old APP/PS1KI mice $58.063 \pm$ $14.027 \mathrm{pg} / \mathrm{mg}$ w.w.). The $\mathrm{A} \beta_{x-42}$ levels in 2-month-old TBA2 mice $(410.2 \pm 43.04$ pg/mg w.w.) were $\sim 85$-fold lower than in age-matched APP/PS1KI mice, which reflects the considerable plaque load already present in APP/PS1KI mice at that time point. (Fig. 3a). In WT mice 
Fig. 2 Characterization of TBA2 transgenic mice. Picture of a wildtype $(W T)$ and a $T B A 2$ mouse showing that $T B A 2$ mice are generally smaller (a) and that they display a crooked posture (b). c Both female and male TBA2 mice showed a reduced body weight compared with their age-matched WT littermates. d Macroscopic analysis of TBA2 brains revealed an atrophic cerebellum when compared with agematched WT littermates. e TBA2 mice displayed a significantly reduced survival rate compared with WT littermates $(P=0.0002$; Logrank test)

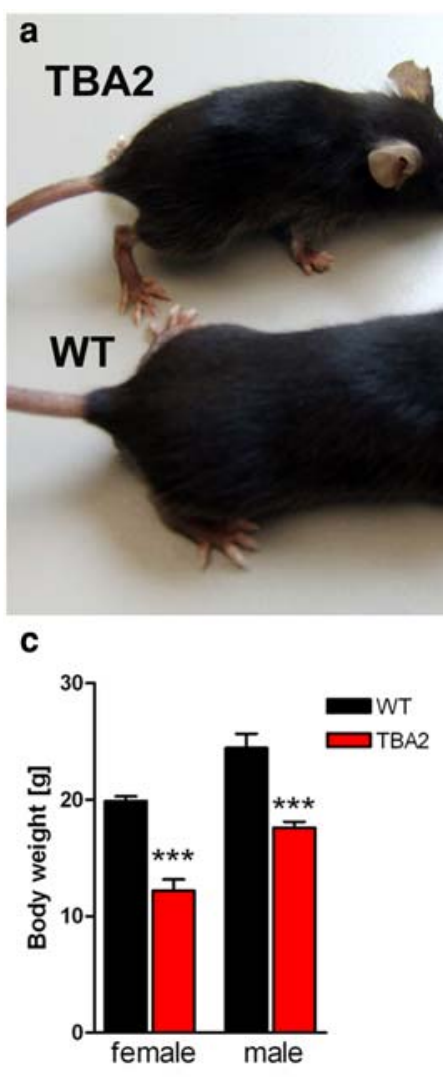

b

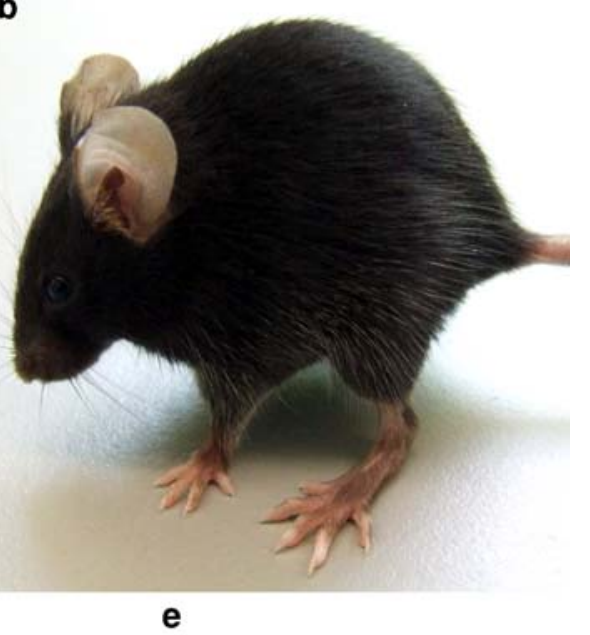

d
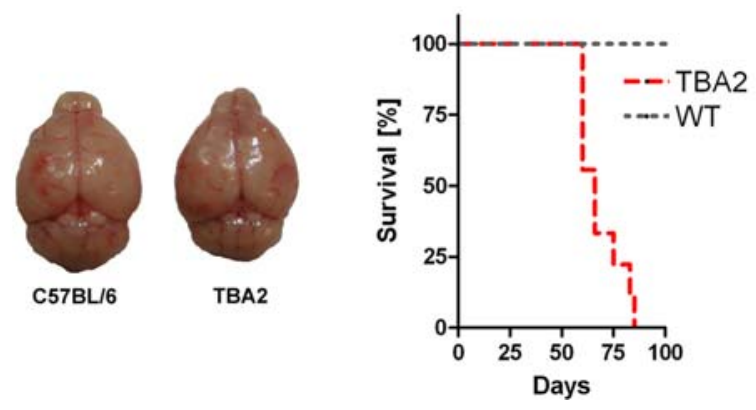
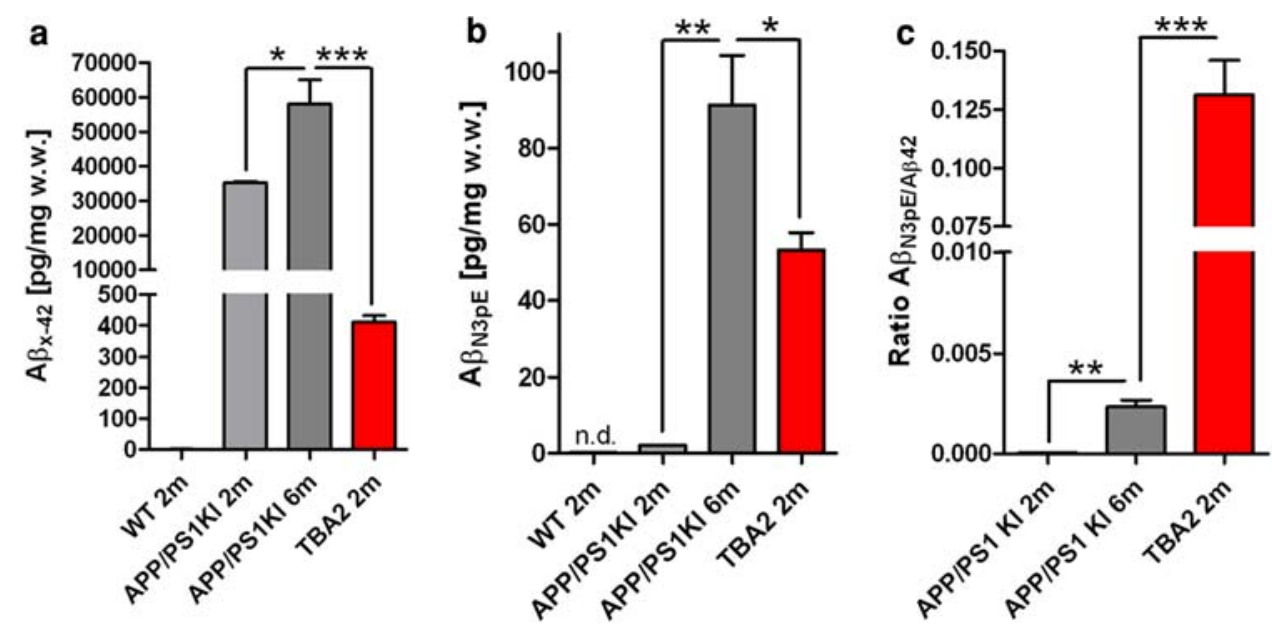

Fig. 3 ELISA measurements of $A \beta_{x-42}$ and $A \beta_{3(\mathrm{pE})}$ in brain hemisphere lysates of WT, APP/PS1KI and TBA2 mice. The A $\beta_{x-42}$ levels in 2-month-old TBA2 mice were $\sim 85$-fold lower than in agematched APP/PS1KI mice (a). APP/PS1KI mice at 2 months of age showed detectable $A \beta_{3(\mathrm{pE})}$ levels increasing $\sim 43$-fold in 6-month-old

mice. TBA2 mice also revealed considerable high $\mathrm{A} \beta_{3(\mathrm{pE})}$ levels, which were, however, significantly lower than in the 6-month-old APP/PS1KI mice $(P<0.05)(\mathbf{b})$. TBA2 mice revealed a more than 50-fold higher $\mathrm{A} \beta_{3(\mathrm{pE})} / \mathrm{A} \beta_{x-42}$ ratio compared with 6-month-old APP/ PS1KI mice $(P<0.001)(\mathbf{c})$

$\mathrm{A} \beta_{3(\mathrm{pE})}$ was undetectable by ELISA (Fig. 3b). APP/PS1KI mice at 2 months of age showed detectable $\mathrm{A} \beta_{3(\mathrm{pE})}$ levels $(2.120 \pm 0.017 \mathrm{pg} / \mathrm{mg}$ w.w. $)$, which increased $\sim 43$-fold in 6-month-old APP/PS1KI mice $(91.32 \pm 26.16 \mathrm{pg} / \mathrm{mg}$ w.w.). Analysis of TBA2 mice (53.23 $\pm 9.18 \mathrm{pg} / \mathrm{mg} \mathrm{w} . w$. also revealed considerable high $\mathrm{A} \beta_{3(\mathrm{pE})}$ levels, which were, however, significantly lower than in the 6-month-old APP/ PS1KI mice $(P<0.05)$ (Fig. 3b). Interestingly, TBA2 mice revealed a more than 50 -fold $\mathrm{A} \beta_{3(\mathrm{pE})} / \mathrm{A} \beta_{x-42}$ increased ratio than 6-month-old APP/PS1KI mice $(0.1313 \pm 0.03$ vs. $0.0023 \pm 0.0007 ; P<0.001$ ), confirming the assumption that TBA2 mice produce high amounts of modified 
$\mathrm{A} \beta_{3(\mathrm{pE}-42)}$ (Fig. 3c). The same profile was obtained by Western blot analysis (Supplementary Fig. 1).

Neuropathological assessment of TBA2 mice

Consistently, TBA2 brain sections showed strong immunoreactivity using antibody 4G8 against $\mathrm{A} \beta$ (epitope $17-$ 24) predominantly in CA1 pyramidal neurons and in Purkinje cells (Fig. 4a, c, d). Neurons in other brain areas were also positive, but the immunoreactivity was less abundant. Diffuse plaques were observed in many brain areas including cortex, cerebellum, thalamus (Fig. 4b), and other areas, but were less prominent as compared to intraneuronal staining (Table 1). Interestingly, low number of plaques were detected in the cerebellar white matter (not shown), whereas most $A \beta$ immunoreactivity was found associated with Purkinje cells (Fig. 4c-e). The observation of extracellular plaques in many brain ares demonstrates that $A \beta$ is also secreted. The neurological phenotype of the TBA2 line resembles that of mouse models with Purkinje cell degeneration (for example [5]). Many, but not all, Purkinje cells were positive for $A \beta_{3(\mathrm{pE})}$ (Fig. 4e, f). Neuropathological analysis of TBA2 mice demonstrated neurodegeneration of Purkinje cells by several observations: abundant micro- and astrogliosis was observed in the cerebellar molecular layer (Fig. $4 \mathrm{~g}-\mathrm{j}$ ). Double stainings using 4G8 (red) and ubiquitin (green) showed a colocalization of $\mathrm{A} \beta$ peptides and ubiquitin, a marker for protein degradation in the cerebellar Purkinje cell layer (Fig. 4k). In addition, double stainings revealed $\mathrm{A} \beta$ peptides within calbindin-positive Purkinje cells (arrows and inset in Fig. 4i) and indicated a loss of calbindin-positive Purkinje cells Fig. 4l, m). Interestingly, we observed extracellular $\mathrm{A} \beta$ deposition, which was associated with the site of Purkinje cell loss (asterisk in Fig. 4m). The neuropathological observations correlate well with the age-dependent neurological deficits (Supplementary videos 1-3) and cerebellar atrophy in the TBA2 model (Fig. 2d). We did not observe any staining using antibodies against hyperphosphorylated Tau (AT8 and PS199) or activated caspase-3 (a marker for apoptosis). Double staining of $A \beta$ and cathepsin $D$ revealed a partial overlap demonstrating intracellular distribution in the late endosomal/lysosomal compartment (Supplementary Fig. 2).

\section{Discussion}

Mice transgenic for the human APP gene have been proven valuable model systems for $\mathrm{AD}$ research. Early pathological changes, including deficits in synaptic transmission [24], changes in behavior, differential glutamate responses, and deficits in long-term potentiation [39] have been reported in several studies. In addition, learning deficits $[2,15,21,43,48]$ and reduced brain volume [4] were evident in transgenic APP models. Interestingly, extracellular amyloid deposition did not correlate with the behavioral phenotype $[22,67]$. These deficits occurred well before plaque deposition became prominent and may, therefore, reflect early pathological changes, likely induced by intraneuronal APP/A $\beta$ mistrafficking or intraneuronal $\mathrm{A} \beta$ accumulation (reviewed in [1]). The coincidence of intracellular $A \beta$ with behavioral deficits supporting an early role of intracellular $A \beta$ has been recently demonstrated in a mouse model containing the Swedish and Arctic mutations [27, 34]. In accordance with these findings, we have previously shown that intraneuronal $A \beta$ accumulation precedes plaque formation in transgenic mice expressing mutant APP695 with the Swedish, Dutch, and London mutations in combination with mutant PS-1 M146L. These mice displayed abundant intraneuronal $A \beta$ immunoreactivity in hippocampal and cortical pyramidal neurons [69]. An even more pronounced phenotype was observed in another transgenic mouse model, expressing Swedish and London mutant APP751 together with mutant PS-1 M146L [3]. In young mice, a strong intraneuronal $A \beta$ staining was detected in vesicular structures in somatodendritic and axonal compartments of pyramidal neurons and an attenuated neuronal immunoreactivity with increasing age. The intraneuronal immunoreactivity declined with increased plaque accumulation [70], a finding which was also reported in Down's syndrome patients, where the youngest patients displayed the strongest immunoreactivity [40]. The neuronal loss in CA1 of the hippocampus did not correlate with the amount of extracellular $\mathrm{A} \beta[4,8]$. The same observation has been reported in the APP/ PS1M146L model [57]. Hippocampal neuron loss has also been reported in the APP23 mouse model [7], however whether intraneuronal $A \beta$ contributes to the neuron loss in this model is not clear. The triple-transgenic mouse model expresses mutant APP in combination with mutant PS-1 and mutant Tau protein. These mice displayed early synaptic dysfunction before plaque or tangle deposition was evident, together with early intraneuronal $A \beta$ immunoreactivity preceding plaque deposition. Tau and $A \beta$ immunoreactivity colocalized in hippocampal neurons, which might imply that early intraneuronal $A \beta$ accumulation could affect Tau pathology [44]. All these AD mouse models express full-length APP, and also C-terminal fragments and $\mathrm{A} \beta$ peptides after cleavage. It is, therefore, difficult to decipher the pathological function of specific $A \beta$ peptides.

In order to specifically investigate the neurotoxicity of $\mathrm{A} \beta_{3 \mathrm{pE}-42}$ generation in vivo, we have generated transgenic mice expressing $A \beta_{3 Q-42}$ starting at position 3 with 

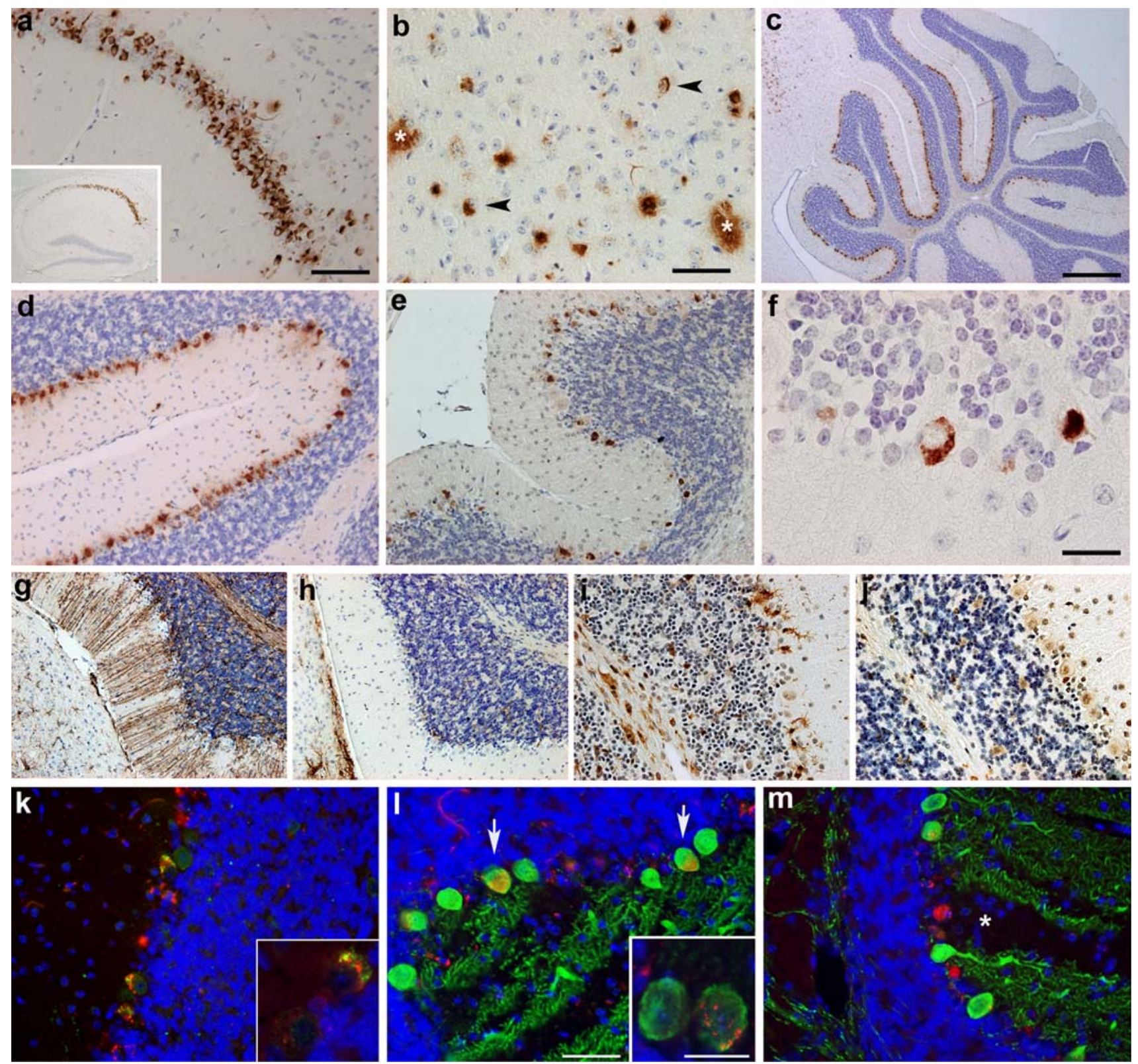

Fig. 4 Immunohistochemical staining of TBA2 mouse brain (2month-old). a Immunostaining with $4 \mathrm{G} 8$ revealed strong $\mathrm{A} \beta$ accumulation in the CA1 pyramidal layer of the hippocampus (inset shows a hippocampus overview at low magnification). b Intra- (arrowhead) and extracellular $\mathrm{A} \beta$ (asterisk) in the thalamus shown by 4G8 staining. c, d A $\beta$ staining (4G8) in the cerebellum is almost completely restricted to the Purkinje cell layer. e, f Most Purkinje cells accumulated pyroglutamate- $\mathrm{A} \beta$ as shown by an antibody against $\mathrm{A} \beta_{3(\mathrm{pE})}$. g GFAP staining of a TBA2 mouse revealed prominent Bergmann glia immunoreactivity, whereas wildtype animals (h) were consistently negative. The microglia marker Iba1 revealed microglia

glutamine and ending with position 42 (TBA2 mouse line). Owing to the replacement of $\mathrm{N}$-terminal glutamate by glutamine, the $\mathrm{A} \beta$ peptides are more prone to conversion into pyroglutamate [54]. The severity of the neurological phenotype observed in TBA2 mice, accompanied with the clusters surrounding Purkinje cells and in white matter tracts in TBA2 mice (i), but not in wildtype littermates (j). k Immunostaining of Purkinje cells with 4G8 (red) and anti-ubiquitin (green) antibodies showing abundant ubiquitin immunoreactivity in 4G8-positive Purkinje cells. I, m Staining of Purkinje cells using antibodies against calbindin (green) and 4G8 (inset shows high magnification of a 4G8and calbindin-positive Purkinje cell). Note absent calbindin (asterisk) and extracellular A $\beta$ staining indicating Purkinje cell loss. Only 4G8positive remnants can be seen. Scale bars $\mathbf{a}, \mathbf{d}, \mathbf{e}, \mathbf{g}-\mathbf{j} 100 \mu \mathrm{m} ; \mathbf{b}, \mathbf{k}-\mathbf{m}$ $50 \mu \mathrm{m} ; \mathbf{c} 500 \mu \mathrm{m}$; $\mathbf{f}$ inset $\mathbf{k}, \mathbf{l} 20 \mu \mathrm{m}$

Purkinje cell loss and premature mortality reflects the in vivo toxicity of $A \beta_{3(\mathrm{pE})-42}$. However, we cannot rule out that unprocessed $A \beta_{3 Q-42}$ has been stabilized by $A \beta_{3(\mathrm{pE})-42}$ accumulation, and might also contribute to the observed neurological phenotype. In addition, the level of $A \beta_{3(\mathrm{pE})-42}$ 
Table 1 Distribution and semi-quantitative description of intraneuronal and plaque-associated $\mathrm{A} \beta$ pathology based on 4G8 immunostaining

\begin{tabular}{llc}
\hline Brain region & Intraneuronal A $\beta$ & Plaques \\
\hline Olfactory bulb & + & + \\
Cortex & + l++ & + \\
Hippocampus & +++ & - \\
Thalamus & $(+)$ & ++ \\
Superior colliculus & ++ & ++ \\
Midbrain & + & + \\
Pons & + & ++ \\
Medulla & ++ & $+/++$ \\
Cerebellum & & \\
Purkinje cell layer & +++ & - \\
White matter & - & ++ \\
Granule cell layer & - & - \\
Molecular layer & - & \\
\hline
\end{tabular}

in 6-month-old APP/PS1KI mice was comparable to that of 2 -month-old TBA2 mice. However, $85 \%$ of A $\beta$ peptides in the APP/PS1KI mice terminated at position 42 , the N-terminus shows a large heterogeneity including $A \beta_{3(\mathrm{pE})}$. The time point of high levels of $A \beta_{3(\mathrm{pE})-42}$ coincided with the onset of behavioral deficits in both mouse models. In addition, only a fraction of Purkinje cells showed abundant levels of intracellular $A \beta_{3(\mathrm{pE})}$ accumulation leading to the assumption that only those are prone for degeneration (Fig. 4). We have previously shown that at 6 months, the APP/PS1KI mice exhibit a neuron loss in CA1 of the hippocampus [4, 8], the frontal cortex [11], and in distinct cholinergic nuclei [10]. Recently, a transgenic mouse model expressing human APP with the 714 austrian mutation has been reported showing intraneuronal $A \beta$ accumulation correlating with brain atrophy [65]. Overall, the pathological events seen in the APP/PS1KI mouse model might be at least partly triggered by $A \beta_{3(\mathrm{pE})-42}$ accumulation however the TBA2 mouse model is the only one expressing $A \beta_{3(\mathrm{pE})-42}$ without any of the other $A \beta$ peptides.

Amyloid precursor protein transgenic mouse models have been reported to show no [29] or low $A \beta_{3(\mathrm{pE})}$ levels [18]. Maeda et al. have demonstrated that the localization and abundance of [11C]PIB autoradiographic signals were closely associated with those of amino-terminally truncated and modified $A \beta_{3 p E}$ deposition in $\mathrm{AD}$ and different $\mathrm{APP}$ transgenic mouse brains, implying that the detectability of amyloid by [11C]PIB-PET is dependent on the accumulation of specific $A \beta$ subtypes [35]. There is an interesting coincidence of considerable amounts of $A \beta_{3(\mathrm{pE})}$ and massive neuron loss in the APP/PS1KI mouse model [1, 8]. An emerging role of intracellular $A \beta$ accumulation has been previously shown in human $\mathrm{AD}[13,17]$. It has been observed that $\mathrm{A} \beta$ localizes predominantly to abnormal endosomes [9], multivesicular bodies, and within pre- and postsynaptic compartments [31, 61]. Takahashi et al. demonstrated that $A \beta 42$ aggregates into oligomers within endosomal vesicles and along microtubules of neuronal processes, both in $\mathrm{Tg} 2576$ neurons with time in culture, as well as in Tg2576 and human AD brain [60]. In good agreement with these reports, we observed that $\mathrm{A} \beta$ is also localized in the late endosomal/lysosomal compartment in the TBA2 model. Owing to the large heterogeneity of N-truncated $A \beta_{x-42}$ peptides in the APP/PS1KI model, it is impossible to study the role of a single $A \beta$ variant. In the TBA2 model, however, we were able to demonstrate the intraneuronal $A \beta_{3(\mathrm{pE})-42}$ aggregation induced neuron loss without contribution of extracellular $A \beta$ aggregation.

$N$-truncated $A \beta_{3(\mathrm{pE})}$ peptides have been identified by several groups from AD brains $[18,19,23,25,28,29,38$, $41,45,46,49,52,53,63]$. In addition, other N-terminal truncated peptides have been identified such as $A \beta_{5-40 / 42}$ [62], $\mathrm{A} \beta_{11-40 / 42}[32,33]$, and Flemish and Dutch N-terminally truncated amyloid beta peptides [14]. Cai et al. have demonstrated that secretion of $A \beta_{1-40 / 42}$ and $A \beta_{11-40 /}$ 42 is abolished in BACE1-/- neurons establishing that BACE1 is the principal $\beta$-secretase for endogenous APP in neurons. Although $A \beta_{11-40 / 42}$ peptides have been observed in neuronal cultures and in the brains of patients with $A D$, the involvement of these peptides in its pathogenesis remains to be elusive [6]. In general, N-terminal deletions enhance aggregation of $\beta$-amyloid peptides in vitro [47]. $\mathrm{A} \beta_{3(\mathrm{pE})}$ has a higher aggregation propensity $[20,55]$ and stability [30], and shows an increased toxicity compared with full-length $A \beta$ [51]. It has been suggested that N-truncated $A \beta$ peptides are formed directly by BACE and not through a progressive proteolysis of full-length $\mathrm{A} \beta_{1-40 / 42}$ [50].

In in vitro experiments Schilling et al. have shown that the cyclization of glutamate at position 3 of $A \beta$ is driven enzymatically by glutaminyl cyclase (QC) [54]. In addition, it has been shown that QC inhibition significantly reduced $A \beta_{3(\mathrm{pE})}$ formation, emphasizing the importance of QC activity during the cellular maturation of pyroglutamate-containing peptides. The pharmacological inhibition of QC activity by the QC inhibitor P150, which significantly reduced the level of $A \beta_{3(\mathrm{pE})}$ in vitro [12] and in vivo [56] suggests that QC inhibition might serve as a new therapeutic approach to rescue $A \beta_{3(\mathrm{pE})}$ triggered neurodegeneration in human disorders.

$\mathrm{A} \beta$ accumulation has an important function in the etiology of AD with its typical clinical symptoms, such as memory impairment and changes in personality. However, the mode of this toxic activity is still a matter of scientific debate. Previously, we have shown that the APP/PS1KI 
mouse model develops severe learning deficits at 6 months of age correlating with a CA1 neuron loss and an atrophy of the hippocampus $[4,8]$, together with a drastic reduction of long-term potentiation and disrupted paired pulse facilitation. This was accompanied by reduced levels of preand post-synaptic markers. We also observed that intraneuronal and not plaque-associated $\mathrm{A} \beta$ including $\mathrm{N}$ modified $A \beta_{3(\mathrm{pE})-42}$ species increased and coincided well with CA1 neuron loss, however the dominant species was $\mathrm{A} \beta_{1-42}$ in the APP/PS1KI model. In good agreement with this study, we could show for the first time that intraneuronal $A \beta_{3(\mathrm{pE})-42}$ accumulation is sufficient for triggering neuron death and inducing an associated neurological phenotype in a novel transgenic mouse model (TBA2 mice). The $A \beta$ staining in the cerebellum was completely restricted to the intraneuronal compartment further supporting the notion that intraneuronal pathology is instrumental in neuron loss and that extracellular plaque deposition has no drastic effect on cell survival.

Acknowledgments Financial support was provided by the European Commission, Marie Curie Early Stage Training, MEST-CT2005-020013 (NEURAD), Alzheimer Ph.D. Graduate School, the Research program of the Faculty of Medicine, Georg-August-University Göttingen and Alzheimer Forschung Initiative e.V. (to O.W.) and a Klaus Murmann-Ph.D.-scholarship from the Foundation of German Businesses (to H.B.). Disclosure statement: H.U.D. is a shareholder, H.C. and S.S. are employees, T.A.B. is a scientific consultant of Probiodrug.

Open Access This article is distributed under the terms of the Creative Commons Attribution Noncommercial License which permits any noncommercial use, distribution, and reproduction in any medium, provided the original author(s) and source are credited.

\section{References}

1. Bayer TA, Wirths O (2008) Review on the APP/PS1KI mouse model: intraneuronal $A \beta$ accumulation triggers axonopathy, neuron loss and working memory impairment. Genes Brain Behav 7(Suppl 1):6-11

2. Billings LM, Oddo S, Green KN, McGaugh JL, Laferla FM (2005) Intraneuronal Abeta causes the onset of early Alzheimer's disease-related cognitive deficits in transgenic mice. Neuron 45:675-688

3. Blanchard V, Moussaoui S, Czech C, Touchet N, Bonici B, Planche M, Canton T, Jedidi I, Gohin M, Wirths O, Bayer TA, Langui D, Duyckaerts C, Tremp G, Pradier L (2003) Time sequence of maturation of dystrophic neuritis associated with Abeta deposits in APP/PS1 transgenic mice. Exp Neurol 184:247-263

4. Breyhan H, Wirths O, Duan K, Marcello A, Rettig J, Bayer TA (2009) APP/PS1KI bigenic mice develop early synaptic deficits and hippocampus atrophy. Acta Neuropathol 117:677-685

5. Burright EN, Clark HB, Servadio A, Matilla T, Feddersen RM, Yunis WS, Duvick LA, Zoghbi HY, Orr HT (1995) SCA1 transgenic mice: a model for neurodegeneration caused by an expanded CAG trinucleotide repeat. Cell 82:937-948
6. Cai H, Wang Y, McCarthy D, Wen H, Borchelt DR, Price DL, Wong PC (2001) BACE1 is the major beta-secretase for generation of Abeta peptides by neurons. Nat Neurosci 4:233-234

7. Calhoun ME, Wiederhold KH, Abramowski D, Phinney AL, Probst A, Sturchler-Pierrat C, Staufenbiel M, Sommer B, Jucker M (1998) Neuron loss in APP transgenic mice. Nature 395:755-756

8. Casas C, Sergeant N, Itier JM, Blanchard V, Wirths O, van der Kolk N, Vingtdeux V, van de Steeg E, Ret G, Canton T, Drobecq H, Clark A, Bonici B, Delacourte A, Benavides J, Schmitz C, Tremp G, Bayer TA, Benoit P, Pradier L (2004) Massive CA1/2 neuronal loss with intraneuronal and $\mathrm{N}$-terminal truncated Abeta42 accumulation in a novel Alzheimer transgenic model. Am J Pathol 165:1289-1300

9. Cataldo AM, Petanceska S, Terio NB, Peterhoff CM, Durham R, Mercken M, Mehta PD, Buxbaum J, Haroutunian V, Nixon RA (2004) Abeta localization in abnormal endosomes: association with earliest Abeta elevations in $\mathrm{AD}$ and Down syndrome. Neurobiol Aging 25:1263-1272

10. Christensen DZ, Bayer TA, Wirths O (2008) Intracellular Abeta triggers neuron loss in the cholinergic system of the APP/PS1KI mouse model of Alzheimer's disease. Neurobiol Aging. doi: 10.1016/j.neurobiolaging.2008.07.022

11. Christensen DZ, Kraus SL, Flohr A, Cotel MC, Wirths O, Bayer TA (2008) Transient intraneuronal Abeta rather than extracellular plaque pathology correlates with neuron loss in the frontal cortex of APP/PS1KI mice. Acta Neuropathol 116:647-655

12. Cynis H, Schilling S, Bodnar M, Hoffmann T, Heiser U, Saido TC, Demuth HU (2006) Inhibition of glutaminyl cyclase alters pyroglutamate formation in mammalian cells. Biochim Biophys Acta 1764:1618-1625

13. D'Andrea MR, Nagele RG, Wang HY, Lee DH (2002) Consistent immunohistochemical detection of intracellular beta-amyloid42 in pyramidal neurons of Alzheimer's disease entorhinal cortex. Neurosci Lett 333:163-166

14. Demeester N, Mertens C, Caster H, Goethals M, Vandekerckhove J, Rosseneu M, Labeur C (2001) Comparison of the aggregation properties, secondary structure and apoptotic effects of wild-type, Flemish and Dutch N-terminally truncated amyloid beta peptides. Eur J Neurosci 13:2015-2024

15. Gimenez-Llort L, Blazquez G, Canete T, Johansson B, Oddo S, Tobena A, LaFerla FM, Fernandez-Teruel A (2007) Modeling behavioral and neuronal symptoms of Alzheimer's disease in mice: a role for intraneuronal amyloid. Neurosci Biobehav Rev $31: 125-147$

16. Gorevic PD, Goni F, Pons-Estel B, Alvarez F, Peress NS, Frangione B (1986) Isolation and partial characterization of neurofibrillary tangles and amyloid plaque core in Alzheimer's disease: immunohistological studies. J Neuropathol Exp Neurol 45:647-664

17. Gouras GK, Tsai J, Naslund J, Vincent B, Edgar M, Checler F, Greenfield JP, Haroutunian V, Buxbaum JD, Xu H, Greengard P, Relkin NR (2000) Intraneuronal Abeta42 accumulation in human brain. Am J Pathol 156:15-20

18. Guntert A, Dobeli H, Bohrmann B (2006) High sensitivity analysis of amyloid-beta peptide composition in amyloid deposits from human and PS2APP mouse brain. Neuroscience 143:461475

19. Harigaya Y, Saido TC, Eckman CB, Prada CM, Shoji M, Younkin SG (2000) Amyloid beta protein starting pyroglutamate at position 3 is a major component of the amyloid deposits in the Alzheimer's disease brain. Biochem Biophys Res Commun 276:422-427

20. He W, Barrow CJ (1999) The Abeta 3-pyroglutamyl and 11-pyroglutamyl peptides found in senile plaque have greater beta-sheet forming and aggregation propensities in vitro than full-length Abeta. Biochemistry 38:10871-10877 
21. Holcomb L, Gordon MN, McGowan E, Yu X, Benkovic S, Jantzen P, Wright K, Saad I, Mueller R, Morgan D, Sanders S, Zehr C, O'Campo K, Hardy J, Prada CM, Eckman C, Younkin S, Hsiao K, Duff K (1998) Accelerated Alzheimer-type phenotype in transgenic mice carrying both mutant amyloid precursor protein and presenilin 1 transgenes. Nat Med 4:97-100

22. Holcomb LA, Gordon MN, Jantzen P, Hsiao K, Duff K, Morgan D (1999) Behavioral changes in transgenic mice expressing both amyloid precursor protein and presenilin-1 mutations: lack of association with amyloid deposits. Behav Genet 29:177-185

23. Hosoda R, Saido TC, Otvos L Jr, Arai T, Mann DM, Lee VM, Trojanowski JQ, Iwatsubo T (1998) Quantification of modified amyloid beta peptides in Alzheimer disease and Down syndrome brains. J Neuropathol Exp Neurol 57:1089-1095

24. Hsia AY, Masliah E, McConlogue L, Yu GQ, Tatsuno G, Hu K, Kholodenko D, Malenka RC, Nicoll RA, Mucke L (1999) Plaqueindependent disruption of neural circuits in Alzheimer's disease mouse models. Proc Natl Acad Sci USA 96:3228-3233

25. Iwatsubo T, Saido TC, Mann DM, Lee VM, Trojanowski JQ (1996) Full-length amyloid-beta (1-42(43)) and amino-terminally modified and truncated amyloid-beta 42(43) deposit in diffuse plaques. Am J Pathol 149:1823-1830

26. Klein WL (2002) Abeta toxicity in Alzheimer's disease: globular oligomers (ADDLs) as new vaccine and drug targets. Neurochem Int 41:345-352

27. Knobloch M, Konietzko U, Krebs DC, Nitsch RM (2007) Intracellular Abeta and cognitive deficits precede beta-amyloid deposition in transgenic arcAbeta mice. Neurobiol Aging 28:1297-1306

28. Kuo YM, Emmerling MR, Woods AS, Cotter RJ, Roher AE (1997) Isolation, chemical characterization, and quantitation of A beta 3-pyroglutamyl peptide from neuritic plaques and vascular amyloid deposits. Biochem Biophys Res Commun 237:188-191

29. Kuo YM, Kokjohn TA, Beach TG, Sue LI, Brune D, Lopez JC, Kalback WM, Abramowski D, Sturchler-Pierrat C, Staufenbiel M, Roher AE (2001) Comparative analysis of amyloid-beta chemical structure and amyloid plaque morphology of transgenic mouse and Alzheimer's disease brains. J Biol Chem 276:1299112998

30. Kuo YM, Webster S, Emmerling MR, De Lima N, Roher AE (1998) Irreversible dimerization/tetramerization and post-translational modifications inhibit proteolytic degradation of A beta peptides of Alzheimer's disease. Biochim Biophys Acta 1406:291-298

31. Langui D, Girardot N, El Hachimi KH, Allinquant B, Blanchard V, Pradier L, Duyckaerts C (2004) Subcellular topography of neuronal Abeta peptide in $\mathrm{APP} \times \mathrm{PS} 1$ transgenic mice. Am J Pathol 165:1465-1477

32. Lee EB, Skovronsky DM, Abtahian F, Doms RW, Lee VM (2003) Secretion and intracellular generation of truncated Abeta in beta-site amyloid-beta precursor protein-cleaving enzyme expressing human neurons. J Biol Chem 278:4458-4466

33. Liu K, Solano I, Mann D, Lemere C, Mercken M, Trojanowski JQ, Lee VM (2006) Characterization of Abeta11-40/42 peptide deposition in Alzheimer's disease and young Down's syndrome brains: implication of $\mathrm{N}$-terminally truncated Abeta species in the pathogenesis of Alzheimer's disease. Acta Neuropathol (Berl) 112:163-174 (Epub 2006 Jun 2001)

34. Lord A, Englund H, Soderberg L, Tucker S, Clausen F, Hillered L, Gordon M, Morgan D, Lannfelt L, Pettersson FE, Nilsson LN (2009) Amyloid-beta protofibril levels correlate with spatial learning in Arctic Alzheimer's disease transgenic mice. FEBS J 276:995-1006

35. Maeda J, Ji B, Tomiyama T, Maruyama M, Okauchi T, Staufenbiel M, Iwata N, Ono M, Saido TC, Suzuki K, Mori M, Higuchi M, Suhara T (2007) Longitudinal, quantitative assessment of amyloid, neuroinflammation and anti-amyloid treatment in a living mouse model of Alzheimer's disease enabled by PET. J Neurosci 27:10957-10968

36. Masters CL, Simms G, Weinman NA, Multhaup G, McDonald BL, Beyreuther K (1985) Amyloid plaque core protein in Alzheimer disease and Down syndrome. Proc Natl Acad Sci USA 82:4245-4249

37. McLean CA, Cherny RA, Fraser FW, Fuller SJ, Smith MJ, Beyreuther K, Bush AI, Masters CL (1999) Soluble pool of Abeta amyloid as a determinant of severity of neurodegeneration in Alzheimer's disease. Ann Neurol 46:860-866

38. Miravalle L, Calero M, Takao M, Roher AE, Ghetti B, Vidal R (2005) Amino-terminally truncated Abeta peptide species are the main component of cotton wool plaques. Biochemistry 44:10810-10821

39. Moechars D, Dewachter I, Lorent K, Reverse D, Baekelandt V, Naidu A, Tesseur I, Spittaels K, Haute CV, Checler F, Godaux E, Cordell B, Van Leuven F (1999) Early phenotypic changes in transgenic mice that overexpress different mutants of amyloid precursor protein in brain. J Biol Chem 274:6483-6492

40. Mori C, Spooner ET, Wisniewsk KE, Wisniewski TM, Yamaguch H, Saido TC, Tolan DR, Selkoe DJ, Lemere CA (2002) Intraneuronal Abeta42 accumulation in Down syndrome brain. Amyloid 9:88-102

41. Mori H, Takio K, Ogawara M, Selkoe DJ (1992) Mass spectrometry of purified amyloid beta protein in Alzheimer's disease. J Biol Chem 267:17082-17086

42. Naslund J, Haroutunian V, Mohs R, Davis KL, Davies P, Greengard P, Buxbaum JD (2000) Correlation between elevated levels of amyloid beta-peptide in the brain and cognitive decline. JAMA 283:1571-1577

43. Oakley H, Cole SL, Logan S, Maus E, Shao P, Craft J, GuillozetBongaarts A, Ohno M, Disterhoft J, Van Eldik L, Berry R, Vassar R (2006) Intraneuronal beta-amyloid aggregates, neurodegeneration, and neuron loss in transgenic mice with five familial Alzheimer's disease mutations: potential factors in amyloid plaque formation. J Neurosci 26:10129-10140

44. Oddo S, Caccamo A, Kitazawa M, Tseng BP, LaFerla FM (2003) Amyloid deposition precedes tangle formation in a triple transgenic model of Alzheimer's disease. Neurobiol Aging 24:1063-1070

45. Piccini A, Russo C, Gliozzi A, Relini A, Vitali A, Borghi R, Giliberto L, Armirotti A, D'Arrigo C, Bachi A, Cattaneo A, Canale C, Torrassa S, Saido TC, Markesbery W, Gambetti P, Tabaton M (2005) beta-Amyloid is different in normal aging and in alzheimer disease. J Biol Chem 280:34186-34192

46. Piccini A, Zanusso G, Borghi R, Noviello C, Monaco S, Russo R, Damonte G, Armirotti A, Gelati M, Giordano R, Zambenedetti P, Russo C, Ghetti B, Tabaton M (2007) Association of a presenilin 1 S170F mutation with a novel Alzheimer disease molecular phenotype. Arch Neurol 64:738-745

47. Pike CJ, Overman MJ, Cotman CW (1995) Amino-terminal deletions enhance aggregation of beta-amyloid peptides in vitro. J Biol Chem 270:23895-23898

48. Puolivali J, Wang J, Heikkinen T, Heikkila M, Tapiola T, van Groen T, Tanila H (2002) Hippocampal A beta 42 levels correlate with spatial memory deficit in APP and PS1 double transgenic mice. Neurobiol Dis 9:339-347

49. Russo C, Saido TC, DeBusk LM, Tabaton M, Gambetti P, Teller JK (1997) Heterogeneity of water-soluble amyloid beta-peptide in Alzheimer's disease and Down's syndrome brains. FEBS Lett 409:411-416

50. Russo C, Salis S, Dolcini V, Venezia V, Song XH, Teller JK, Schettini G (2001) Amino-terminal modification and tyrosine phosphorylation of [corrected] carboxy-terminal fragments of the amyloid precursor protein in Alzheimer's disease and Down's syndrome brain. Neurobiol Dis 8:173-180 
51. Russo C, Violani E, Salis S, Venezia V, Dolcini V, Damonte G, Benatti U, D'Arrigo C, Patrone E, Carlo P, Schettini G (2002) Pyroglutamate-modified amyloid-peptides-AbetaN3(pE)strongly affect cultured neuron and astrocyte survival. J Neurochem 82:1480-1489

52. Saido TC, Iwatsubo T, Mann DM, Shimada H, Ihara Y, Kawashima S (1995) Dominant and differential deposition of distinct beta-amyloid peptide species, Abeta N3(pE), in senile plaques. Neuron 14:457-466

53. Saido TC, Yamao-Harigaya W, Iwatsubo T, Kawashima S (1996) Amino- and carboxyl-terminal heterogeneity of beta-amyloid peptides deposited in human brain. Neurosci Lett 215:173-176

54. Schilling S, Hoffmann T, Manhart S, Hoffmann M, Demuth HU (2004) Glutaminyl cyclases unfold glutamyl cyclase activity under mild acid conditions. FEBS Lett 563:191-196

55. Schilling S, Lauber T, Schaupp M, Manhart S, Scheel E, Bohm G, Demuth HU (2006) On the seeding and oligomerization of pGlu-amyloid peptides (in vitro). Biochemistry 45:12393-12399

56. Schilling S, Zeitschel U, Hoffmann T, Heiser U, Francke M, Kehlen A, Holzer M, Hutter-Paier B, Prokesch M, Windisch M, Jagla W, Schlenzig D, Lindner C, Rudolph T, Reuter G, Cynis H, Montag D, Demuth HU, Rossner S (2008) Glutaminyl cyclase inhibition attenuates pyroglutamate Abeta and Alzheimer's disease-like pathology. Nat Med 14:1106-1111

57. Schmitz C, Rutten BP, Pielen A, Schafer S, Wirths O, Tremp G, Czech C, Blanchard V, Multhaup G, Rezaie P, Korr H, Steinbusch HW, Pradier L, Bayer TA (2004) Hippocampal neuron loss exceeds amyloid plaque load in a transgenic mouse model of Alzheimer's disease. Am J Pathol 164:1495-1502

58. Selkoe DJ (2001) Alzheimer's disease: genes, proteins, and therapy. Physiol Rev 81:741-766

59. Selkoe DJ, Abraham CR, Podlisny MB, Duffy LK (1986) Isolation of low-molecular-weight proteins from amyloid plaque fibers in Alzheimer's disease. J Neurochem 46:1820-1834

60. Takahashi RH, Almeida CG, Kearney PF, Yu F, Lin MT, Milner TA, Gouras GK (2004) Oligomerization of Alzheimer's betaamyloid within processes and synapses of cultured neurons and brain. J Neurosci 24:3592-3599

61. Takahashi RH, Milner TA, Li F, Nam EE, Edgar MA, Yamaguchi H, Beal MF, Xu H, Greengard P, Gouras GK (2002) Intraneuronal Alzheimer abeta42 accumulates in multivesicular bodies and is associated with synaptic pathology. Am J Pathol 161:1869-1879
62. Takeda K, Araki W, Akiyama H, Tabira T (2004) Aminotruncated amyloid beta-peptide (Abeta5-40/42) produced from caspase-cleaved amyloid precursor protein is deposited in Alzheimer's disease brain. FASEB J 18:1755-1757

63. Tekirian TL, Saido TC, Markesbery WR, Russell MJ, Wekstein DR, Patel E, Geddes JW (1998) N-terminal heterogeneity of parenchymal and cerebrovascular Abeta deposits. J Neuropathol Exp Neurol 57:76-94

64. Tseng BP, Kitazawa M, LaFerla FM (2004) Amyloid beta-peptide: the inside story. Curr Alzheimer Res 1:231-239

65. Van Broeck B, Vanhoutte G, Pirici D, Van Dam D, Wils H, Cuijt I, Vennekens K, Zabielski M, Michalik A, Theuns J, De Deyn PP, Van der Linden A, Van Broeckhoven C, Kumar-Singh S (2008) Intraneuronal amyloid beta and reduced brain volume in a novel APP T714I mouse model for Alzheimer's disease. Neurobiol Aging 29:241-252

66. Walsh DM, Tseng BP, Rydel RE, Podlisny MB, Selkoe DJ (2000) The oligomerization of amyloid beta-protein begins intracellularly in cells derived from human brain. Biochemistry 39:10831-10839

67. Wirths O, Breyhan H, Schäfer S, Roth C, Bayer TA (2008) Deficits in working memory and motor performance in the APP/ PS1ki mouse model for Alzheimer's disease. Neurobiol Aging 29:891-901

68. Wirths O, Multhaup G, Bayer TA (2004) A modified beta-amyloid hypothesis: intraneuronal accumulation of the beta-amyloid peptide-the first step of a fatal cascade. J Neurochem 91:513520

69. Wirths O, Multhaup G, Czech C, Blanchard V, Moussaoui S, Tremp G, Pradier L, Beyreuther K, Bayer TA (2001) Intraneuronal Abeta accumulation precedes plaque formation in betaamyloid precursor protein and presenilin-1 double-transgenic mice. Neurosci Lett 306:116-120

70. Wirths O, Multhaup G, Czech C, Feldmann N, Blanchard V, Tremp G, Beyreuther K, Pradier L, Bayer TA (2002) Intraneuronal APP/A beta trafficking and plaque formation in betaamyloid precursor protein and presenilin-1 transgenic mice. Brain Pathol 12:275-286

71. Wirths O, Weis J, Kayed R, Saido TC, Bayer TA (2007) Agedependent axonal degeneration in an Alzheimer mouse model. Neurobiol Aging 28:1689-1699 